\title{
Lumen
}

Selected Proceedings from the Canadian Society for Eighteenth-Century Studies

\section{Rousseau and Werther, in Search of a Sympathetic Soul}

\section{Ellie Kennedy}

Volume 19, 2000

Material Productions \& Cultural Construction

Culture matérielle \& Constructions discursives

URI : https://id.erudit.org/iderudit/1012319ar

DOI : https://doi.org/10.7202/1012319ar

Aller au sommaire du numéro

Éditeur(s)

Canadian Society for Eighteenth-Century Studies / Société canadienne d'étude du dix-huitième siècle

ISSN

1209-3696 (imprimé)

1927-8284 (numérique)

Découvrir la revue

Citer cet article

Kennedy, E. (2000). Rousseau and Werther, in Search of a Sympathetic Soul. Lumen, 19, 109-119. https://doi.org/10.7202/1012319ar

Copyright (c) Canadian Society for Eighteenth-Century Studies / Sociéte canadienne d'étude du dix-huitième siècle, 2000
Ce document est protégé par la loi sur le droit d'auteur. L'utilisation des services d'Érudit (y compris la reproduction) est assujettie à sa politique d'utilisation que vous pouvez consulter en ligne.

https://apropos.erudit.org/fr/usagers/politique-dutilisation/ 


\section{Rousseau and Werther: in Search of a Sympathetic Soul}

In 1774 an up-and-coming young dramatist named Goethe published his first novel, Die Leiden des jungen Werther, then and now hailed as a literary masterpiece of its time. In the figure of Werther, the generation of Sturm und Drang and Empfindsamkeit found a voice. A few years later, Romanticism would adopt him as a hero also. Since these literary movements were greatly influenced by the philosophies of Jean-Jacques Rousseau (1712-78), some scholars have pointed to a relationship between Werther and Rousseau's œuvre. On the surface Rousseau's Julie, ou la Nouvelle Héloïse (1761) seems the most obvious point of comparison, as it is also an epistolary novel involving a love triangle. Generally overlooked by critics, however, is that, as a monologue, Die Leiden des jungen Werther bears more similarity to Rousseau's autobiography, or Confessions (1782-89). ${ }^{1}$ In fact, a comparison of the two works proves extremely worthwhile.

Although Confessions was published several years after Werther, Rousseau's public readings from his autobiography in Paris in 1770 caused a storm, reverberations from which were felt much further afield. Furthermore, Rousseau's philosophies, while outlined in the Confessions, had been published in his lifetime, and therefore belonged in the public domain during what would have been the formative years of the young protagonist Werther. The briefest of glances reveals many similarities between the figure of Werther and the self-portrait which Rousseau paints in the Confessions: to name but a few, both have a real affinity with nature; both love passionately and obsessively; both exhibit a tendency to choose unattainable women as the object of their affections; and both love literature probably as much as anything else in their lives. In these two works, each man is seen writing his own story, indeed, writing himself, and it is in this respect that they will be compared here. Furthermore, both, in writing themselves, appear to seek a particular kind of communication. In Werther's Goethe and the Game of Literary Creativity, Deirdre Vincent (writing not of Werther but of his creator) claims: 
In the course of his life Goethe came to form a clear image in his mind of the type of person for whom he wrote as one who shared his goals and preoccupations and for whom his works were therefore readily accessible. Fundamental to the poet's image of the ideal reader was a belief that the act of reading, when properly carried out, was in itself a creative act, a productive encounter for the reader between minds on the same wavelength. Without the right kind of readers, whom Goethe termed "kindred spirits" ("verwandte Wesen"), the act of writing would be purely egotistical. (5)

This paper argues that the above, whatever its implications for Goethe, in fact describes the communication strategy adopted by Werther in his letters. Second, the paper aims to show how this strategy mirrors that adopted by Rousseau in his Confessions. Third, it argues that Werther and Rousseau employ their respective narratives first to seek and then to construct the above-mentioned kindred spirits (or 'sympathetic souls') for themselves. ${ }^{2}$ Finally, it examines why for both the search is ultimately doomed.

From the outset, Rousseau as a writing subject strives to establish a distinct Self whose essence is contained within and expressed in terms of the heart, or the soul. The preface to the Confessions states:

My purpose is to display to my kind a portrait in every way true to nature, and the man I shall portray will be myself. Simply myself. I know my own heart and understand my fellow man. But I am made unlike any one I have ever met; I will even venture to say that I am like no one in the whole world. I may be no better, but at least I am different. Whether nature did well or ill in breaking the mould in which she formed me, is a question which can only be resolved after [reading me]. (17)

It is immediately apparent that Rousseau wishes the reader to judge him. In subsequent chapters it becomes increasingly clear that he intends to direct that judgement himself: Rousseau, as a public figure, feels that he has been misjudged both in public and in private, and he uses his Confessions as a vehicle for his own point of view. This does not mean that he will always put himself in the right or display himself in the most flattering light - far from it. In fact, he attempts to lay bare his character so that the reader will understand why, in every case, Rousseau acted as he did.

In relating his life-story as an old man, Rousseau actually re-lives important positive and negative experiences through the medium of feeling. Of one occasion he writes: 'I feel my pulse beat faster once more as I write. I shall always remember that time if I live to be a thousand' (30). He takes great pleasure in re-creating, and hence re-living, his 
idyllic childhood years in the countryside, and yet the pleasure of portraying himself as 'vile and despicable' appears even greater. Sometimes a negative self-portrayal is motivated by a need to unburden his conscience (for example in the episode from his youth where he falsely implicated another for his own stealing), but generally it is motivated by a deeper need connected with Rousseau's self-confessed masochism. He relates in great detail the first spanking he received from his beloved guardian aunt, the unexpected pleasure which this gave him, and the fact that this experience at a tender age fixed his sexual preferences for life (25). It soon becomes apparent that a similar masochistic pleasure is obtained from revealing to the reader those aspects of his character which are 'ridiculous' and 'shameful' (28). Just as the 26-year-old Rousseau develops - and acts upon - the urge to lurk in dark alleyways, displaying his buttocks to passing servant girls, so too is the 50-year-old in his autobiography motivated by the need to expose himself completely: 'Since I have undertaken to reveal myself absolutely to the public, nothing about me must remain hidden or obscure' (65). He relentlessly displays every skeleton in his closet, and relishes the shame he feels in the telling. ${ }^{3}$ His Confessions are a veritable orgy of self-exposure.

As a narrative strategy, then, Rousseau's self-exposure serves a twin aim. On the one hand, it brings pleasure to the teller to reveal himself either as 'vile and despicable' or as 'good, generous and noble' (17) as he considers appropriate. On the other hand, such pleasure is subordinate to a greater goal, that which Weinstein refers to as: 'the perpetual crisis of Rousseau's life: to make his heart and soul visible' (233). In fact, the need to expose himself in writing, to make himself transparent, is not an end in itself, but is motivated by the search for a sympathetic soul. In part 2 of the Confessions, Rousseau describes the perfect wife he never found:

The first, the greatest, the strongest, the most inextinguishable of all my needs was entirely one of the heart. It was the need for intimate companionship .... This singular need was such that the most intimate physical union could not fulfil it; only two souls in the same body would have sufficed. (386)

Jean-Jacques' romanticised version of his parents' courtship portrays theirs as exactly such a relationship (17), but Rousseau himself experiences the ideal union only during childhood with his cousin Bernard (24, 30). In both episodes the heart, functioning as metonym for the Self, seeks and finds a sympathetic heart to which it can open itself. ${ }^{4}$ To know someone's 'heart' (or 'soul') is to know the person truly. Not having found such a sympathetic soul in the course of his adult life, the autobiographer Rousseau tries opening his heart to his readers. Near the 
beginning of his book he breaks off a detailed description of one of his character traits to remark: 'But as the reader learns more of my life, he will get to know my disposition and feel all this for himself without my needing to tell him' (45). A few chapters later, confident that this communication strategy is succeeding, he remarks: 'The reader might be surprised to find me [responding thus], if he had not grown used to my peculiarities by now' (154). Thus the perfect relationship for Rousseau is one where verbal communication is no longer necessary, for each person is understood completely by the other. ${ }^{5}$

Unfortunately, the attempt to find a sympathetic soul in the reader is doomed to failure for three reasons. First, in the Confessions Rousseau is addressing 'the numberless legion of my fellow men' (17). If intimate communion with individuals has failed, the attempt to commune with the public at large is surely an unrealistic goal. Second, a paradox is evident from the beginning of the preface: Rousseau wishes to display himself to his 'kind,' and yet, as he says in the next paragraph, he is unique. Thus, to find a heart akin to his must be an impossible task. Third, the perfect communication he seeks must surely be a reciprocal phenomenon, and yet readers, in reading, can only receive, they cannot bare their own souls to Rousseau in return. Although he appears to long for communication, Rousseau actually seeks self-affirmation in the form of a listening ear which reflects and thereby validates his own feelings and convictions. To a certain extent, he succeeds. As Weinstein says: 'Listening, blushing, moaning, confessing, Rousseau's readers respond to his language with precisely those powerful emotions that he himself so loved and feared throughout his life.... The reader, then, is Rousseau's final partner, to be wooed, convinced, and coerced. Rousseau exposes himself ever more hugely, because, the fuller a say he has the more assuredly he can command assent' (244). Rousseau may succeed in convincing the reader of facts, and he may even succeed in transmitting to the reader his feelings. Furthermore, as a historical figure he may receive the validation he desires: his own version of himself may be the one to go down in history. However, since writing is a one-way form of communication he will not, through writing himself, find the sympathetic soul he seeks. He remains ultimately alone, turning to himself, to nature, to his books and his fantasies, to fill the void.

Rousseau's quest for a sympathetic soul has profound implications for the cult of friendship emerging in his day. Jau $\beta$ characterizes the entire Empfindsamkeit movement as: 'seit und durch Rousseau als sympathetische Erfahrung der "schönen Seelen" eröffnet' (603). Unsurprisingly, this is the view of friendship, of communication, which drives Die Leiden des jungen Werther. Not only is Werther's infatuation with Lotte motivated by the search for a sympathetic soul, but so too is his narrative. 
A reading of Werther with respect to the above discussion of Rousseau's Confessions throws considerable light on Werther's communication strategies. Like Rousseau, Werther elegizes compulsively: he is continually harking back to a past idyll of rural bliss and perfect friendship, in particular that which he enjoyed with his now-dead childhood sweetheart: 'ich habe das Herz gefühlt, die große Seele, in deren Gegenwart ich mir schien mehr zu sein, als ich war, weil ich alles war, was ich sein konnte' (12). Arriving in the beautiful countryside of Wahlheim, Werther creates another idyll for himself, where he initially desires communion with nature: 'man möchte zum Maienkäfer werden, um in dem Meer von Wohlgerüchen herumschweben und alle seine Nahrung darin finden zu können' (8). He then progresses to a desire for communion with the beautiful Charlotte. The young woman as an individual plays little part in Werther's narrated version of their relationship, which instead makes use of his subjective ideal of Lotte. ${ }^{6}$ In his narrative, Werther aims to construct a perfect harmony between them, which he generally expresses through literary references. For Werther, as for Rousseau, literature and nature belong to the inner Self, thus the choice of literature as the means of expression for his relationship with Lotte demonstrates that he responds to her with his innermost being. $\mathrm{He}$ convinces himself, and may even convince the reader, that his adored one feels the same way, that here is the sympathetic soul for whom he yearns. However, even if Lotte were to feel this way, she would never be his alone, and thus the relationship could never truly be fulfilled.

Werther lives the Lotte-idyll for about seven weeks until it is shattered by the inevitable return of her fiancé Albert. ${ }^{7}$ Werther's reaction is telling: first, he deplores all change, reacting with uncharacteristic violence to the felling of local walnut trees (80); second, he tries to return to the past by losing himself in the ancient world of Ossian (82); and third, he visits his childhood home for the first time in years (72). It is not the past per se which Werther desires, but his own childhood. ${ }^{8}$ From the beginning Werther creates a cult of childhood (e.g. 30), which is why he loses his heart to Lotte the moment he sees her surrounded by adoring little ones (21). A longing to return to childhood is Rousseauian in the extreme, recalling the Confessions, but perhaps even more so the Discourse on the Origin of Inequality where the progress of individual men and of society is portrayed as a loss of childhood innocence. ${ }^{9}$ Although Werther appears to be longing for the union of sympathetic souls that he enjoyed with his dead childhood sweetheart, he actually longs for the whole childhood state, with its attendant lack of responsibility and its total self-indulgence and egocentricity.

What, then, is Werther really seeking through his narrative? Like Rousseau, he creates a distinct Self, the seat of whose uniqueness is the 
heart: 'Ach, was ich wei $\beta$, kann jeder wissen - mein Herz habe ich allein' (74). But, also like Rousseau, he craves communication, or rather, selfaffirmation through communion with another. ${ }^{10}$ In the suicide discussion with Albert, Werther puts himself firmly outside everyday society, referring to 'ihr Menschen' and 'ihr vernünftigen Leute,' and claiming that he belongs to the 'außerordentlichen Menschen,' denounced by society as drunk or mad. He then goes on to expound his philosophy of life, declaring of suicide victims: 'denn nur insofern wir mitempfinden, haben wir Ehre, von einer Sache zu reden' (48). Weinstein maintains that this displays generosity of spirit, that Werther insists on putting himself in another's situation before judging (162). However, Werther's insistence on his own point of view during this discussion, coupled with his terminology (i.e. 'mitempfinden'), can also be read as a (Rousseauian) desire to impose his own feelings on others. In fact, nowhere in the narrative do we see Werther providing the listening, understanding ear which he himself is seeking. As far as we know, his 'intimate' friend Lotte has never spoken to him about her feelings for him, or for her fiancé. In her book on Schwärmertum, Maria Leonarda Castello points out: 'Jedes Gespräch zwischen Werther und [Lotte] hat letztlich monologischen Charakter.... Jeder verharrt in seiner Perspektive und unterdrückt damit sich und die anderen' (62). For example, while Werther is secretly planning to leave Wahlheim, Lotte is musing on the after-life, wondering if she will be reunited with her dead mother. Werther's reaction is to place himself at the centre of her musings, taking her 'sollen wir uns wieder finden?' (57) to refer to his own impending departure. As Castello says: 'So gewinnt er den Eindruck, Lotte wüßte um sein Geheimnis, was auf eine tiefe, wortlose Verbundenheit zwischen ihnen verwiese' (55). Just as Rousseau attempts to construct the reader as a sympathetic soul, Werther tries to construct Lotte as such for himself. Moreover, in Werther's musings on the childhood idyll with his 'Freundin,' the line 'weil ich alles war, was ich sein konnte' (12, emphasis added) betrays Werther's self-focus and demonstrates that his chief aim in seeking a sympathetic soul is self-fulfillment. Any talk of sharing is as questionable for him as it is for Rousseau. Werther, believing it is his lot to be misunderstood, seeks someone who will understand him, and thereby validate his feelings and his Self. It is of only secondary importance to understand that someone in return.

Failing to find a sympathetic soul among his acquaintances Werther, like Rousseau, turns to the reader, although for him 'reader' does not mean quite the same thing. His chosen medium is the letter, a very intimate form of communication, ${ }^{11}$ and yet his correspondent, Wilhelm, as Pütz appropriately remarks: 'bedeutet ihm nicht viel mehr als der Adressat eines nach außen gestülpten Selbstgesprächs' (57). Why does 
his supposed intimate friend Wilhelm not provide the sympathetic soul that Werther seeks? Werther certainly seems to presume that the ideal, wordless, form of communication exists between them, as these lines from the opening of his first letter demonstrate: 'Dich zu verlassen, den ich so liebe, von dem ich unzertrennlich war, und froh zu sein! Ich wei $\beta$, du verzeihst mir's' (7). This certainty of his friend's forgiveness could indeed be construed as knowledge born of true intimacy, and hence correct anticipation of Wilhelm's reaction. More likely, however, it is a strategy for eliciting a particular reaction (in this case forgiveness). Further, Werther tells Wilhelm everything but never solicits his opinion and advice, or even inquires after his health or state of mind. Even alluded-to replies (to which we are, of course, not privy) concern Werther alone (e.g. 101). Wilhelm himself has no existence beyond the letters which Werther writes. ${ }^{12}$ This is not to suggest that Werther is writing to an imaginary friend, but rather that Wilhelm, in the context of Werther's letters, functions merely as a rhetorical device. Werther employs this device in several ways, but primarily to strengthen his own point of view. ${ }^{13}$ By anticipating or replying to 'Wilhelm's' voice of reason, he argues all the more forcefully that the strength of his passions denies and defies all logical reasoning (e.g. 43).

For Werther, the Wilhelm-device is more than a clever oratorical stratagy; it is absolutely essential. In the letter of Sept 4th, he declares: 'Doch wozu das alles? warum behalt' ich nicht für mich, was mich ängstigt und kränkt? warum betrüb' ich noch dich? warum geb' ich dir immer Gelegenheit, mich zu bedauern und mich zu schelten? Sei's denn, auch das mag zu meinem Schicksal gehören!' (77). Like Rousseau, Werther cannot keep his story to himself; he needs a receptacle for the outpourings of his soul. For him, the epistolary mode of narration is the ideal one, and yet his 'correspondent' can only be ficitious. ${ }^{14}$

Thus Werther is not trying to construct Wilhelm as a sympathetic soul, but is using him as a device to sway the reader. But who is Werther's reader? Rousseau knows his own readership, and it is two-fold. It comprises, on the one hand, his own circle of acquaintances, many of whom he feels have wronged or misjudged him, and in this respect his book is a way of settling old scores. ${ }^{15}$ On the other hand, the Confessions is addressed to a wider circle, i.e. the general public, who, if the desired effect is attained, should agree with Rousseau, empathize with his feelings, love him, and see him as he wishes to be seen. ${ }^{16}$ Werther too addresses a smaller and a larger public. In the Eighteenth Century it was quite common for letters received by an individual to be circulated among friends and acquaintances (almost like sending email today). Thus on the one hand Werther's letters are meant for his family and friends. Twice, he specifically addresses himself to this group, blaming 
them for his disastrous interlude as an ambassador's secretary: 'Und daran seid ihr alle schuld' (62); 'und ihr seid doch allein schuld daran' (67). On the other hand, like Rousseau, Werther also seems to speak to the public at large. At least once, he addresses the whole world: 'Ja wohl bin ich nur ein Wandrer, ein Waller auf der Erde! Seid ihr denn mehr?' (75). To put it somewhat unkindly, he believes that the world revolves around him; thus it is perfectly natural for him to address the public as a whole. One might say that throughout the novel, Werther is addressing 'the reader,' the anonymous reading public, in the same way as does Rousseau. The epistolary mode, the 'Briefpartner' and the occasional remark addressed to his wider circle of acquaintances are all devices aimed at turning the reader into a sympathetic soul for Werther. ${ }^{17}$ If this strategy is successful, the reader will sympathize, empathize with Werther, and will accept his narrative one hundred per cent, thereby validating and affirming his point of view, his self-portrayal and, most importantly of all, his feelings.

It seems appropriate at this point to consider the question: could Werther and Rousseau communicate with one another, could each be the sympathetic soul for which the other believes he is searching? The answer, of course, has to be a resounding 'no!' Neither would find what he is looking for, because neither is seeking a sympathetic soul (although each believes he is) so much as validation and affirmation of his self-image and uniqueness. Unfortunately, since the 'reader' is both anonymous and incapable of direct response, the writer cannot ever receive the wished-for affirmation. This is less the case for Rousseau, who does receive a considerable amount of validation in the form of publication and recognition (although he remains a bitter old hermit to the end). For Werther, however, it is tragic. His friends and relations do not empathize with his feelings or agree with his point of view, and although he addresses the world at large, he has no reason to think that his words will ever reach the general public.

Paradoxically (for he will never know it), Werther does succeed in reaching others: his final meeting with Lotte and his subsequent death both profoundly affect the object of his affections, who at the close of the novel lies dangerously ill. As Weinstein says: 'The project of overcoming distance, of touching another, has succeeded, even if disastrously' (164). Moreover, upon publication of the work, Werther's feelings did receive the desired affirmation, for contemporary readers were moved to 'mitempfinden' with him to an astonishing degree: 'Da sitz' ich mit zerfloßnem Herzen, mit klopfender Brust und mit Augen, aus welchen wollüstiger schmerz tröpfelt, und sag Dir, Leser, daß ich eben 'Die Leiden des jungen Werthers' von meinem lieben Goethe - gelesen? nein, verschlungen habe.... Kauf's Buch und lies selbst! Nimm aber dein 
Herz mit! ${ }^{18}$ Werther, however, as a fictional character trapped inside his own epistolary novel, will never have access to this external reaction. His letters, like all suicide attempts, constitute a cry for attention, but tragically they remain: 'Briefe ohne Echo, ohne Hoffnung auf Echo' (Miller 212). Unable to attain the affirmation he needs, Werther's despair becomes insurmountable and he takes his own life.

\section{ELLIE KENNEDY}

Queen's University

\section{Notes}

1 Wuthenow (28-29) does go beyond the comparison with La Nouvelle Héloïse to list elements of Werther which are Rousseauistic in a general sense. Meanwhile, Arnold Weinstein's Fictions of the Self: 1500-1800 contains a chapter on Werther and one on the Confessions, but unfortunately does not compare them.

2 Note that it is Werther's communicative aims which are considered here. Whether or not these concur with the aims of his creator, Goethe, is a subject for another paper.

3 As Weinstein says in Fictions of the Self: 'where no legitimizing alibi can be found, he is left in the ultimately gratifying position of enjoying his misery' (237).

4 For example, of his parents he claims: ' both threw their affections at the first heart that opened to receive them' (17), and of his time at Bossey with Bernard: 'The simplicity of this rural existence ... opened my heart to friendship' (24).

5 As De Mijolla puts it: 'If they continue to read, Rousseau's Confessions will become their own. They will lose the innocence of their difference from Rousseau. Rousseau's actions and emotions will become part of his readers' experience' (94).

6 In his article 'Werthers Leiden an der Literatur,' Peter Pütz remarks: 'Dem Empfindsamen ist alles außerhalb seines Ichs Existierende, sogar das intentionale Objekt seines Begehrens, zweitrangig, wenn nicht gar belanglos. Wenn Werther liebt, so steht für ihn nicht die Geliebte im Mittelpunkt, sondern die Tatsache des Verliebtseins, das sich gerade von der Aussichtslosigkeit als Quelle all seiner Leiden und Freuden nährt' (67).

7 Werther's reaction to the loss of his idyll at first appears to be similar to Rousseau's. The latter's childhood idyll of perfect friendship in a beautiful rural setting ended through false accusation and wrongful punishment, which is narrated like the fall from paradise. Rousseau claims: 'From that moment I never again enjoyed pure happiness' (30). However, in narrating at least two subsequent episodes, when travelling through the countryside, he utters statements such as: 'I do not remember ever having had in all my life a spell of time so completely free from care and anxiety as those seven or eight days we spent on the road' (64). Although he tends to dwell on his misfortunes, he is able to enjoy happiness, if briefly, again. For Werther, however, the loss of his 
Lotte-idyll is unbearable, and signifies the beginning of the end. His thoughts take a turn towards violence and death; his heart feels increasingly constricted, both literally and metaphorically.

8 Clues to this effect are strewn throughout the entire narrative. As early as his third letter Werther declares: 'Auch halte ich mein Herzchen wie ein krankes Kind; jeder Wille wird ihm gestattet' (10).

9 Howells summarizes the Discours sur l'origine de l'inégalité thus: 'There Part I presents man in the state of nature, a creature of instinct, independent, spontaneous and innocent. Part II traces change, and the development through social relations of human self-consciousness and moral freedom. But, because social relations are bad, this is also the development of corruption and alienation. That is the actual history of the race, which went terribly wrong. It is also the history of each individual - from infant to adult - which parallels that of the race' (29).

10 Flaschka (162-68) shows how in the text key words suggest a shared world of the soul as an alternative to outer reality.

11 'ein Verständigungsmittel der Seelen, ein gedankliches Band zwischen zwei Personen, die einander so gut kennen, da $\beta$ sie auch intimere Gedanken und Empfindungen sich mitteilen': (Miller, Der empfindsame Erzähler, 148).

12 Blackall would take this further and state that there is no outside world at all: "The striking thing about the novel is the unity of its standpoint. It is a novel of obsession, not one of conflict. In form it is a letter-novel without a replying correspondent, and a roman personnel. Except for one brief section we never really move outside Werther's mind. That there is an outside "world" is part of the illusion; and because there is no objective reality, Werther is not, cannot be, in conflict with it. The poignancy of his situation is that he thinks he is: but this sense of conflict is as much an illusion as the outside world with which he feels himself in conflict' (15).

13 Another use of this device is to whet the reader's appetite for the narration to come, for example the letter of June 16 opens: 'Warum ich dir nicht schreibe?' (19), a rhetorical question which provides the perfect opening for a long description of the first meeting with Lotte.

14 Sauder sums up the relationship between the Sturm und Drang writers and the epistolary novel as follows: 'Das außerordentliche Subjekt kann nicht wie bisher mit anderen "korrespondieren", es stö $\beta t$ allenthalben auf den Widerstand der Konvention, erfährt Widerspruch und schließt sich in den extremen Fällen ... aus dem Zirkel der sympathetischen Kommunikation aus' (163).

15 At one point, for example, he directly addresses his friend Marshall Keith, to deny certain rumours claiming that his interest in Keith is purely financial (62).

16 To mask his insecurity, and to insure himself against disappointment, he takes a defiant, provocative tone with them from the outset: 'So let the numberless legion of my fellow men gather round me, and hear my confessions. Let them groan at my depravities, and blush for my misdeeds. But let each one of them reveal his heart at the foot of Thy throne with equal sincerity, and may any man who dares, say "I was a better man than he"' (17).

17 Blackall (53-55) and Miller (155-56) demonstrate how even the fictitious editor's preface and afterword contribute to the construction of the reader as sympathetic soul. 
18 Christian Daniel Schubart in Deutsche Chronik, $5^{\text {th }}$ December, 1774. Quoted in 'Quellen und Daten zur Geschichte des "Werther" Romans,' Goethe, Werke (Hamburg: dtv, 1981) vol 6:1, 528.

\section{Works Cited}

Blackall, Eric E. Goethe and the Novel. Ithaca: Cornell U.P., 1976.

Blessin, Stefan. Johann Wolfgang Goethe: Die Leiden des jungen Werther. Frankfurt: Diesterweg, 1985.

Castello, Maria Leonarda. Schwärmertum und Gewalt in Goethes Werther, Tiecks William Lovell und Büchners Lenz. Würzburg: Hauck, 1993.

De Mijolla, Elizabeth. 'Rousseau: Confessions, Dialogues, Reveries.' Autobiographical Quests: Augustin, Montaigne, Rousseau and Wordsworth. Charlottesville and London: UP of Virginia, 1994. 78-114.

Flaschka, Horst. Goethes Werther: Werkkontextualle Deskription und Analyse. Munich: Fink, 1987.

Goethe, Johann Wolfgang. Die Leiden des jungen Werther. 1774. Vol 6 of Johann Wolfgang von Goethe: Werke. Ed. Erich Trunz. $10^{\text {th }}$ ed. 14 vols. Hamburger Ausgabe. Hamburg: dtv, 1981. 7-124.

Howells, R.J. Rousseau: La Nouvelle Héloïse. London: Grant and Cutler, 1986.

Jauß, Hans Robert. 'Rousseaus Nouvelle Héloïse und Goethes Werther im Horizontwandel zwischen französischer Aufklärung und deutschem Idealismus.' Ästhetische Erfahrung und literarische Hermeneutik. Nördlingen: Suhrkamp, 1984. 585-653.

Lange, Victor. 'Zur Gestalt des Schwärmers im deutschen Roman des 18. Jahrhunderts,' Festschrift für Richard Alewyn. Ed. Herbert Singer and Benno von Wiese. Cologne: Böhlau, 1967. 151-164.

Miller, Norbert. Der empfindsame Erzähler: Untersuchungen an Romananfängen des 18. Jahrhunderts. Munich: Hanser, 1968.

Pütz, Peter. 'Werthers Leiden an der Literatur,' Goethe's narrative fiction: The Irvine Symposium. Ed. William J. Lillyman. Berlin: de Gruyter, 1983. 56-68.

Rousseau, Jean-Jacques. The Confessions. Trans. J.M. Cohen. Harmondsworth: Penguin, 1953.

Sauder, Gerhard. 'Subjektivität und Empfindsamkeit im Roman,' Sturm und Drang: Ein literaturwissenschaftliches Studienbuch. Ed. Walter Hinck. Kronberg: Athenäum, 1978. 163-174.

Schmidt, Erich. Richardson, Rousseau und Goethe: Ein Beitrag zur Geschichte des Romans im 18. Jahrhundert. Jena: Fromann, 1875.

Vincent, Deirdre. Werther's Goethe and the Game of Literary Creativity. Toronto UP, 1992.

Weinstein, Arnold. Fictions of the Self: 1500-1800. Princeton: UP of Princeton, 1981.

Wuthenow, Ralph-Rainer. 'Rousseau im "Sturm und Drang,"' Sturm und Drang: ein literaturwissenschaftliches Studienbuch. Ed. Walter Hinck. Kronberg: Athenäum, 1978. 14-54. 